\title{
Food anaphylaxis in toddlers: own clinical experience in diagnostic measurement and identification of underlying causes
}

\author{
Anafilaksja pokarmowa u małych dzieci: własne doświadczenia kliniczne \\ w diagnostyce i identyfikacji przyczyn \\ 1 Department of Paediatrics No. 2, Danylo Halytsky Lviv National Medical University, Lviv, Ukraine \\ ${ }^{2}$ Allergy Department, Communal Non-profit Enterprise "City Children's Clinical Hospital of Lviv," Lviv, Ukraine \\ ${ }^{3}$ Department of Propaedeutic Paediatrics and Medical Genetics, Danylo Halytsky Lviv National Medical University, Lviv, Ukraine \\ ${ }^{4}$ Department of Public Health Management, Danylo Halytsky Lviv National Medical University, Lviv, Ukraine \\ ${ }^{5}$ Department of Therapy No. 1 and Medical Diagnostics, Danylo Halytsky Lviv National Medical University, Lviv, Ukraine \\ Correspondence: Associate Professor, Oksana Matsyura, PhD, Allergy Department, Communal Nonprofit Enterprise"City Children's Clinical Hospital of Lviv,"4 Pylyp Orlyk Street, 79059 Lviv, Ukraine, \\ tel.: +38 097305 92 73, e-mail: omatsyura@gmail.com
}

\begin{abstract}
The article presents current data on the reasons for the occurrence, peculiarities of the course, and diagnostic principles of anaphylaxis in toddlers. The determination of protein group enables to prognosticate the risk of development of food anaphylaxis. A comprehensive method is the ALEX in vitro multiplex allergy test. In the first reported case, anaphylaxis appeared after the consumption of a milk formula (cutaneous and respiratory symptoms; five months) and buckwheat (cutaneous, gastrointestinal, and respiratory symptoms; 11 months). On examination, the storage proteins of buckwheat Fag e 2 were detected $-22.82 \mathrm{kU} \mathrm{A}_{\mathrm{A}} / \mathrm{L}$ and major components of milk Bos d 4 ( $\alpha$-lactalbumin) $-41.37 \mathrm{kU}_{\mathrm{A}} / \mathrm{L}$, Bos d 5 ( $\beta$-lactoglobulin) - $41.12 \mathrm{kU}_{\mathrm{A}} / \mathrm{L}$, Bos d 8 (casein) - $32.84 \mathrm{kU}_{\mathrm{A}} / \mathrm{L}$. In the second case, anaphylaxis (cutaneous, gastrointestinal, respiratory, and neurological symptoms) developed after eating cake. On examination, the following storage proteins were detected: hazelnut Cor a $14-6.80 \mathrm{kU}_{\mathrm{A}} / \mathrm{L}$, walnut Jug $\mathrm{r} 1-3.76 \mathrm{kU}_{\mathrm{A}} / \mathrm{L}$. In the third case, anaphylaxis (cutaneous and respiratory symptoms) occurred after contact with dried fish (carp, cod) which the affected child was holding in the hands. On examination, parvalbumins were detected, including Atlantic cod - Gad m $1-46.67 \mathrm{kU} \mathrm{A}_{\mathrm{A}} / \mathrm{L}$, carp - Cyp c $1-42.61 \mathrm{kU}_{\mathrm{A}} / \mathrm{L}$, Atlantic herring - Clu h $1-49.05 \mathrm{kU}_{\mathrm{A}} / \mathrm{L}$, Sal s $1-45.58 \mathrm{kU}_{\mathrm{A}} / \mathrm{L}$, Atlantic mackerel - Sco s $1-48.82 \mathrm{kU}_{\mathrm{A}} / \mathrm{L}$, tuna - Thu a 1 $43.12 \mathrm{kU}_{\mathrm{A}} / \mathrm{L}$, and swordfish - Xip g $1-43.83 \mathrm{kU}_{\mathrm{A}} / \mathrm{L}$. Based on a complex examination, the patients received thorough dietary and lifestyle recommendations, as well as information about health risks and the need for an epinephrine autoinjector.
\end{abstract}

Keywords: food anaphylaxis, diagnosis, multiplex test, cause, toddlers

Streszczenie W wacy przedstawiono aktualne dane dotyczące przyczyn reakcji anafilaktycznej u małych dzieci, specyfiki jej przebiegu oraz procesu diagnostycznego. Ryzyko rozwoju anafilaksji pokarmowej można prognozować na podstawie oznaczenia przeciwciał przeciwko różnym grupom białek. Kompleksową metodą jest m.in. wieloparametrowy test ALEX do diagnostyki in vitro chorób alergicznych. W pierwszym opisanym przypadku reakcja anafilaktyczna wystąpiła po spożyciu mleka modyfikowanego dla niemowląt (objawy skórne i oddechowe; wiek 5 miesięcy) oraz kaszy gryczanej (objawy skórne, żołądkowo-jelitowe i oddechowe; wiek 11 miesięcy). W badaniu wykryto białka spichrzowe gryki Fag e 2 - 22,82 $\mathrm{kU}_{\mathrm{A}} / l$ oraz główne komponenty mleka Bos d 4 ( $\alpha$-laktalbumina) - 41,37 kU $\mathrm{A}_{\mathrm{A}} /$, Bos d 5 ( $\beta$-laktoglobulina) - 41,12 $\mathrm{kU}_{\mathrm{A}} /$, Bos d 8 (kazeina) - 32,84 $\mathrm{kU}_{\mathrm{A}} / \mathrm{l}$. W drugim przypadku anafilaksja (objawy skórne, żołądkowo-jelitowe, oddechowe i neurologiczne) wystąpiła po zjedzeniu przez dziecko ciasta. $\mathrm{W}$ badaniu wykryto następujące białka spichrzowe: orzech laskowy Cor a $14-6,80 \mathrm{kU}_{\mathrm{A}} / 1$, orzech włoski Jug r $1-3,76 \mathrm{kU}_{\mathrm{A}} / \mathrm{l}$. W trzecim przypadku reakcja anafilaktyczna (objawy skórne i oddechowe) pojawiła się po kontakcie skórnym z suszoną rybą (karp, dorsz), którą dziecko trzymało w rękach. W badaniu stwierdzono uczulenie na parwalbuminy: dorsz atlantycki - Gad m 1 -

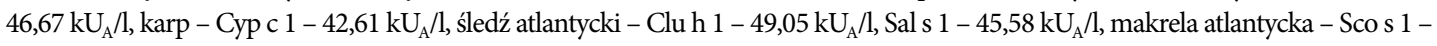

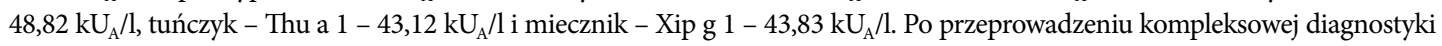
opiekunom pacjentów przekazano szczegółowe zalecenia dietetyczne i dotyczące modyfikacji stylu życia, a także informacje o zagrożeniach zdrowotnych i konieczności posiadania autostrzykawki z adrenaliną na wypadek anafilaksji. 


\section{INTRODUCTION}

A naphylaxis is a severe life-threatening form of a generalised or systemic reaction of hypersensitivity characterised by a rapid onset of hazardous functional failures of the respiratory and circulatory systems. It is also usually associated with clinical manifestations involving the skin and mucous membranes ${ }^{(1)}$.

Anaphylaxis has been seen to develop in $0.5-2.0 \%$ of people during their lifespan ${ }^{(2-4)}$. The main triggers are food, medicines, insects, and latex ${ }^{(2,5)}$. Among the leading products that can cause anaphylaxis in children are milk, eggs, soy and wheat, and in adults - nuts and seafood ${ }^{(6,7)}$. One of the most common causes of fatal effects of food allergens in the general population are peanuts ${ }^{(3,8)}$.

It should be remembered that food anaphylaxis in young children can be accompanied by the development of nonspecific symptoms, such as constant crying, drowsiness, tearfulness, sore throat, anxiety, numbness of the extremities, swallowing, and speech disorders ${ }^{(9)}$. It is difficult to determine the triggers in children, as case records and subjective assessments of complaints are less informative, and often symptoms are transitory or expressed indistinctly. Difficulties in the identification of anaphylaxis in young children due to the prevalence of viral exanthema, respiratory symptoms in viral infections, stomach ache (gastroesophageal reflux, constipation etc.), as well as the development of tachycardia because of crying or discomfort, have all been described in the literature ${ }^{(1,9)}$.

There is a practical classification of the severity of anaphylactic reactions, according to which 3 degrees are distinguished - mild, moderate and severe. Different target organs can be affected, including the skin, gastrointestinal tract, and cardiovascular and neurological systems ${ }^{(10)}$.

The classification of the severity of anaphylactic reactions is given in Tab. $1^{(7)}$.
Skin symptoms are usually present in all young children developing an anaphylactic reaction, and different signs can be observed, such as rash, itching, hyperaemia, and swelling. Moreover, in this age group itching is usually present on the palms, feet, and head; however, it can also be generalised. Gastrointestinal symptoms range from a slight itching or tingling sensation in the mouth, nausea to spastic stomach ache, recurrent vomiting, and diarrhoea. Respiratory symptoms include nasal congestion, rhinorrhoea, hoarseness, bronchospasm, cyanosis, and apnoea. Cardiovascular changes comprise tachycardia, bradycardia, hypotension, collapse, impairment of cardiac rhythm, and cardiac arrest. Neurological symptoms include activity changes, lethargy, delirium, fear of death, confusion, and loss of consciousness $^{(4)}$.

In anaphylaxis, damage to the skin is observed in $80-90 \%$ of children, and involvement of the respiratory tract $-70 \%$, gastrointestinal tract $-30-45 \%$, cardiovascular system $10-45 \%$, and nervous system $-10-15 \%{ }^{(3)}$.

Thus, early acute signs of anaphylaxis are mucous secretions from the nose, itching of the eyes, lips, and ears, and swelling of the face. Severe reactions are associated with the development of bronchospasm and laryngospasm. Abdominal symptoms (acute stomach ache, vomiting, and diarrhoea) and hypotension are also possible $^{(11)}$.

The signs and symptoms of anaphylaxis usually develop from several minutes to two hours after a contact with an allergen. In patients with food allergies, symptoms of IgE-dependent allergy develop usually within 15-30 minutes after product ingestion.

In 2005, a decision was made at the symposium of the Second National Institute of Allergy and Infectious Disease/ Food Allergy and Anaphylaxis Network to establish the diagnosis of anaphylaxis if at least one of the defined three clinical criteria is present ${ }^{(9,12)}$.

\begin{tabular}{|c|c|c|c|c|c|c|}
\hline Degree & $\begin{array}{c}\text { Degree } \\
\text { of severity }\end{array}$ & Skin & Gastrointestinal tract & Respiratory tract & Cardiovascular tract & $\begin{array}{c}\text { Neurological } \\
\text { changes }\end{array}$ \\
\hline 1 & Mild & $\begin{array}{l}\text { Sudden onset of pruritus } \\
\text { of the eyes and nose, } \\
\text { generalised pruritus, } \\
\text { redness, urticaria } \\
\text { or angioedema }\end{array}$ & $\begin{array}{l}\text { Pruritus of the oral cavity, } \\
\text { sensation of tingling in the } \\
\text { mouth, nausea or vomiting, } \\
\text { mild abdominal pain }\end{array}$ & $\begin{array}{l}\text { Nasal congestion and/or } \\
\text { sneezing, rhinorrhoea, } \\
\text { itching in the throat, } \\
\text { or light wheezing }\end{array}$ & $\begin{array}{c}\text { Tachycardia } \\
\text { (growth in }>15 / \mathrm{min} \text { ) }\end{array}$ & $\begin{array}{l}\text { Change in activity, } \\
\text { flaccidity }\end{array}$ \\
\hline 2 & Moderate & Any of the listed & $\begin{array}{l}\text { Any of the listed, spastic } \\
\text { abdominal pain, diarrhoea, } \\
\text { repetitive vomiting }\end{array}$ & $\begin{array}{c}\text { Any of the listed, } \\
\text { hoarseness, cough, difficulty } \\
\text { swallowing, dyspnoea, } \\
\text { wheezing of moderate } \\
\text { intensity }\end{array}$ & Any of the listed & $\begin{array}{l}\text { Delirium, } \\
\text { fear of death }\end{array}$ \\
\hline 3 & Severe & Any of the listed & $\begin{array}{l}\text { Any of the listed, } \\
\text { loss of control over } \\
\text { the symptoms } \\
\text { of the intestinal tract }\end{array}$ & $\begin{array}{l}\text { Any of the listed, cyanosis, } \\
\text { saturation } \leq 92 \% \text {, } \\
\text { respiratory arrest }\end{array}$ & $\begin{array}{l}\text { Hypotension* and/or } \\
\text { collapse, disturbance } \\
\text { of cardiac rhythm, } \\
\text { severe bradycardia } \\
\text { and/or cardiac arrest }\end{array}$ & $\begin{array}{l}\text { Confused } \\
\text { consciousness, los } \\
\text { of consciousness }\end{array}$ \\
\hline \multicolumn{7}{|c|}{$\begin{array}{l}\text { * Hypotension is determined if the indexes of systolic blood pressure are the following: } \\
\cdot 1 \text { month }-1 \text { year old }<70 \mathrm{~mm} \mathrm{Hb} \text {; } \\
\cdot 1-10 \text { years }<[70 \mathrm{~mm} \mathrm{Hb}+(2 \times \text { age })] \text {; } \\
\cdot 11-17 \text { years }<90 \mathrm{~mm} \mathrm{Hb} \text {. } \\
\text { The degree of severity is identified depending on the system that was affected the most. }\end{array}$} \\
\hline
\end{tabular}


The first criterion is the specific nature of clinical symptoms an acute reaction involving the skin and/or mucous membranes and one of the signs below:

A. Respiratory symptoms.

B. Drop of blood pressure or symptoms related to shock $\operatorname{organs}^{(9)}$.

Thus, the first criterion can be described as "SYSTEMICALLY." The second criterion is the correlation between an interval (minutes - hours) and the development of clinical symptoms (two and more of the aforementioned symptoms develop simultaneously) after a contact with an allergen.

A. Involvement of the skin and mucous membranes.

B. Respiratory symptoms.

C. Fall in blood pressure or reduction of associated symptoms.

D. Persistent gastrointestinal symptoms $\mathrm{s}^{(4,10)}$.

Thus, the second criterion can be described as "SYSTEMICALLY AND RAPIDLY."

The third criterion is the development of hypotension after a contact with an allergen (minutes - hours), with a drop in systolic pressure of over $30 \%{ }^{(6,10)}$.

Low systolic pressure is considered if:

- 1 month - 1 year $<70 \mathrm{~mm} \mathrm{Hg}$;

- 1-10 years $<$ [70 $\mathrm{mm} \mathrm{Hg}+(2 \times$ age $)]$;

- 11-17 years $<90 \mathrm{~mm} \mathrm{Hg}$.

The third criterion can be described as "HYPOTENSION."

This classification is rather convenient and has been consistently used in medical practice. In particular, training based on the scheme " 3 CRITERIA OF DIAGNOSTICS" is provided in Lviv's children's allergy centre for parents whose children are at a high risk of developing anaphylaxis. Both patients and their relatives should be provided with exhaustive information to be able to identify the symptoms of anaphylaxis correctly, and give first aid to a child before the ambulance arrives.

\section{AIM OF THE PAPER}

To identify the causes and molecules involved in anaphylaxis in young children, and give comprehensive recommendations to prevent severe episodes in the future.

\section{MATERIALS AND METHODS}

A total of three cases of toddlers suffering severe anaphylaxis were included in the study. Informed consent forms were signed by the parents.

General clinical data (study of anamnesis, physical examination and dynamic monitoring) were collected, and the ALEX test (Macro Array Diagnostics) was conducted.

The new array contains 282 allergen reagents (157 allergenic extracts and 125 molecular components), with a large majority of aeroallergen families and cross-reactive food allergens being represented. A comprehensive method is usually applied in clinical practice to distinguish genuine IgE sensitisation from sensitisation due to cross-reactivity (especially in polysensitised patients), to identify the causes and molecules associated with anaphylaxis, to assess unclear symptoms and unsatisfactory response to treatment, and to improve the assessment of severity and risk aspects in patients. The sample requirement is $100 \mu \mathrm{L}$ of serum or plasma.

The ALEX measuring range for specific $\operatorname{IgE}$ is $0.3-50 \mathrm{kU}_{\mathrm{A}} / \mathrm{L}$ (quantitative) and for total $\mathrm{IgE}$ is $1-2,500 \mathrm{kU} / \mathrm{L}$ (semi-quantitative). The results are expressed as Class $0\left(<0.3 \mathrm{kU}_{\mathrm{A}} / \mathrm{L}\right)$, Class $1\left(0.3-1 \mathrm{kU}_{\mathrm{A}} / \mathrm{L}\right)$, Class $2\left(1-5 \mathrm{kU}_{\mathrm{A}} / \mathrm{L}\right)$, Class 3 $\left(5-15 \mathrm{kU}_{\mathrm{A}} / \mathrm{L}\right)$, and Class $4\left(>15 \mathrm{kU}_{\mathrm{A}} / \mathrm{L}\right)$.

Ethical Committee or Institutional Animal Care and Use Committee Approval: Danylo Halytsky Lviv National Medical University 22/05/2019 No. 5.

\section{RESULTS}

We analysed three cases of anaphylaxis in toddlers who were followed up in the Communal Non-profit Enterprise "City Children's Clinical Hospital of Lviv."

\section{CLINICAL CASE NO. 1}

A boy, 31 months old.

Second-born baby, second delivery. The course of the pregnancy and neonatal period were without any abnormalities. Family anamnesis burdened - the mother suffered from atopic dermatitis.

The first maculopapular rashes appeared on the skin at four months of age. At that time, the mother was only breastfeeding. The family doctor diagnosed atopic dermatitis, and prescribed symptomatic treatment with anti-allergic drugs, and topical emollients.

At five months of age, a milk formula was introduced and an anaphylactic reaction appeared for the first time. The symptoms developed SYSTEMICALLY (cutaneous, gastrointestinal, respiratory) and RAPIDLY (first complaints occurred within seven minutes after the ingestion of the formula). The ambulance crew provided emergency therapy, but the mother then lost the medical report and could not remember any drug names.

After the severe allergic reaction to the infant formula, the parents did not give the child dairy products any more, and bought an adrenaline autoinjector to use in case of acute reactions.

At 11 months old, the child ate buckwheat for the first time and an anaphylactic reaction developed for the second time. The symptoms occurred SYSTEMICALLY (cutaneous, gastrointestinal, respiratory) and RAPIDLY (within 15 minutes after the consumption of the new product). The mother injected the child with epinephrine.

Allergen skin tests were contraindicated in the child because of anaphylaxis in anamnesis.

A complex molecular examination was conducted when the child was a year old. The results obtained for 
specific IgE to milk and its fractions (ALEX test) were: Bos d 4 ( $\alpha$-lactalbumin) - $41.37 \mathrm{kU}_{\mathrm{A}} / \mathrm{L}$ (Class 4), Bos d 5 ( $\beta$-lactoglobulin) - 41.12 $\mathrm{kU}_{\mathrm{A}} / \mathrm{L}$ (Class 4$)$, Bos d 8 (casein) $32.84 \mathrm{kU}_{\mathrm{A}} / \mathrm{L}$ (Class 4$)$.

The results recorded for specific IgE to buckwheat: Fag e $42.55 \mathrm{kU}_{\mathrm{A}} / \mathrm{L}$ (Class 4), Fag e $2-22.82 \mathrm{kU}_{\mathrm{A}} / \mathrm{L}$ (Class 4).

Thus, based on a review of the anamnesis data and laboratory findings, the parents were given a set of recommendations listed below:

1. Complete elimination of milk and its derivatives, and buckwheat from the diet.

2. Availability of two epinephrine autoinjectors. The parents were instructed repeatedly on how to identify the symptoms of anaphylaxis, and were familiarised with the rules and method of emergency drug injection.

3. Second-generation antihistamines and emollients were prescribed as supportive therapy.

\section{Analysis of anaphylaxis cause in the patient}

Storage proteins were detected - Fag e 2. This group can cause severe systemic reactions and anaphylaxis. Sensitisation usually occurs in early childhood.

Major components - casein, $\beta$-lactoglobulin and a-lactalbumin - are responsible for developing an allergy to cow's milk protein.

The molecular characteristics of the major milk proteins are given in Tab. 2.

\section{Casein (Bos d 8)}

Casein is a stable protein which does not change its configuration at high temperatures and under the influence of hydrochloric acid. It is the major milk protein (accounting for $75-80 \%$ of milk content), which is present in the milk of all mammals, and in cases of allergy, allergic cross-reaction can develop to milk of all other kinds.

The casein family has different primary structure and functions. Three of them ( $\alpha \mathrm{S} 1$-casein, $\alpha \mathrm{S} 2$-casein, $\beta$-casein) are calcium-sensitive, while $\kappa$-casein does not have this property. The specificity and intensity of clinical response depend on the type of sensitisation to casein. Sensitisation to aS1casein and $\alpha \mathrm{S} 2$-casein is present in all patients with an allergy, $\kappa$-casein - in $91.7 \%$, $\beta$-casein - in $66.7 \%{ }^{(7)}$.

Proteins are highly resistant to heating, so boiling and pasteurisation have little effect. This is due to the fact that the main epitopes have linear and non-conformational features. Casein has an irregular structure, and a significant number of secondary and tertiary structures. Protein molecules form the so-called casein micelle in which hydrophobic central and hydrophilic outer regions are distinguished. Casein has six major and three minor IgE-binding regions, and five major and one minor IgG-binding regions. It has been assumed that most linear IgE epitopes in casein may cause chronic allergies ${ }^{(8)}$.

Children with a chronic allergy to milk have significantly higher levels of specific IgE antibodies to linear epitopes aS1-casein and $\beta$-casein than children with an acquired tolerance to milk proteins. Casein is a protein which, in most cases, makes it possible to differentiate between the chronic and transitory forms of allergy.

\section{$\beta$-lactoglobulin (Bos d 5)}

$\beta$-lactoglobulin is one of the main allergens to cow's milk belonging to lipocalins. It is a major whey protein, constituting $50 \%$ of its fraction and accounting for approximately $10 \%$ of cow's milk.

The protein is a mixture of dimers and monomers; besides, the number of monomers increases during heating to $70^{\circ} \mathrm{C}$. $\beta$-lactoglobulin is a lipid-binding protein and a transporter of vitamin A. Two forms of $\beta$-lactoglobulin have been studied, differing by two point mutations, so the intensity and duration of the response are different as well. The molecule has many binding epitopes, some of which have a short linear motif and others - large fragments with a trimeric structure. Three groups of major epitopes are distinguished, which have a high binding property. Most epitopes are a marker of chronic allergy to cow's milk ${ }^{(1)}$.

Although attempts are made to approximate the composition of most infant formulas to breast milk, $\beta$-lactoglobulin is absent in breast milk, but it is the dominant whey protein

\begin{tabular}{|c|c|c|c|c|}
\hline Milk protein & Characteristic of component(s) & Concentration in milk (g/L) & Molecular weight (kDa) & $\%$ \\
\hline \multicolumn{5}{|c|}{$20 \%$ whey (about $5 \mathrm{~g} / \mathrm{L}$ ) } \\
\hline$\beta$-lactoglobulin (Bos d 5) & Major & $3-4$ & 18.3 & 10 \\
\hline a-lactalbumin (Bos d 4) & Major & $1-1.5$ & 14.2 & 5 \\
\hline Immunoglobulins (Bos d 7) & Minor & $0.6-1.0$ & 150 & 3 \\
\hline Bovine serum albumin (Bos d 6) & Minor & $0.1-0.4$ & 66.3 & 1 \\
\hline Lactoferrin (Bos d Lactoferrin) & Minor & 0.09 & 80 & Traces \\
\hline \multicolumn{5}{|c|}{$80 \%$ total casein (about $30 \mathrm{~g} / \mathrm{L}$ ) } \\
\hline aS1-casein (Bos d 9) & Major & $12-15$ & 23.6 & 32 \\
\hline aS2-casein (Bos d 10) & Major & $3-4$ & 25.2 & 10 \\
\hline$\beta$-casein (Bos d 11) & Major & $9-11$ & 24.0 & 28 \\
\hline K-casein (Bos d 12) & Major & $3-4$ & 19.0 & 10 \\
\hline
\end{tabular}


in baby formulas. Many companies are working to change the ratio of whey proteins, namely $\beta$-lactoglobulin with a-lactalbumin. An investigation of the formula content showed a significant difference between the amount of $\beta$-lactoglobulin in cow's milk and mixtures with partial or complete hydrolysis ${ }^{(3,13)}$.

$\beta$-lactoglobulin is relatively stable to acid hydrolysis and intestinal proteases, so a part of the protein can remain intact and penetrate through the intestinal wall. Thermal processing decreases the binding property proportionally to the degree of heating. However, in the process of chemical reaction, new antigen components, which are inaccessible for binding in a native molecule, can form in denaturated proteins. After hydrolysis, the binding property of the protein may largely persist, so a reaction can also occur after the consumption of fermented milk products ${ }^{(5,8)}$.

$\beta$-lactoglobulin is usually sensitive to heat denaturation. Patients are at a high risk of reaction after consuming fresh milk and a lower risk after consuming thermally processed milk.

\section{a-lactalbumin (Bos d 4)}

Calcium-binding protein constitutes $25 \%$ of whey and $5 \%$ of total protein in cow's milk. It belongs to the family of hydrolases and consists of amino acids located in two structural regions ( $\alpha$ - i $\beta$ - domains), connected by four disulphide bridges. There are trimeric (conformational) epitopes for immunoglobulin binding in a native protein molecule. However, under the influence of denaturating agents, linear epitopes with a high binding ability are determined, which, in turn, increase protein stability ${ }^{(3)}$. $\alpha$-Lactalbumin is a specific protein. Thus, when allergy to milk is associated only with it, cross-reaction to the milk of other mammals milk is impossible. However, there is a high probability of allergy to meat ${ }^{(1,11)}$. Patients are at a high risk of reaction after consuming fresh milk and a low risk after consuming thermally processed milk.

\section{CLINICAL CASE NO. 2}

A boy, 35 months old.

First-born baby, first delivery. The course of pregnancy and neonatal period were uneventful.

Family anamnesis burdened - the father suffered from bronchial asthma and allergic rhinitis.

First rashes appeared on the skin at two months of age. At that time, the mother was only breastfeeding. A doctor corrected the mother's diet (elimination of all milk products and veal), after which all symptoms regressed. When the child was five months old, the parents introduced a sour milk formula, since the amount of breast milk decreased. During two days of formula consumption the child's condition was gradually worsening - anxiety and crying were observed, and generalised rash appeared on the body. The parents consulted an allergist with the symptoms. The specialist prescribed a formula based on complete protein hydrolysis, which the child ate during the next seven months. Milk-free complementary foods (vegetables, fruit, cereals, meat) were also added according to age.

At 1 year of age, the determination of specific $\operatorname{IgE}$ in the blood was performed (ALEX test) and the following results were obtained: milk - $2.51 \mathrm{kU}_{\mathrm{A}} / \mathrm{L}$ (Class 2), a-lactalbumin $0.60 \mathrm{kU}_{\mathrm{A}} / \mathrm{L}$ (Class 1), $\beta$-lactoglobulin - $3.15 \mathrm{kU}_{\mathrm{A}} / \mathrm{L}$ (Class 2), casein - $1.7 \mathrm{kU}_{\mathrm{A}} / \mathrm{L}$ (Class 2), bovine serum albumin $0.49 \mathrm{kU}_{\mathrm{A}} / \mathrm{L}$ (Class 1), hazelnut - $2.91 \mathrm{kU}_{\mathrm{A}} / \mathrm{L}$ (Class 2). After testing, an oral provocation test with milk was scheduled for the child, and complete elimination of nuts was prescribed. The diagnostic elimination of the product (milk and its derivatives) was conducted four weeks before the trial. All drugs which could interfere with the reaction were postponed, including antihistamines (by 10 days), and glucocorticosteroids (by three weeks).

An oral provocation test with lactose-free milk was performed by the technique proposed by the Veneto Centre for Research Diagnosis and Treatment of Food Allergies and Intolerances, Department of Paediatrics - Padua General University Hospital, Italy (head - Professor Antonella Muraro) $)^{(7)}$.

In the clinic, the child consumed $66 \mathrm{~mL}$ of lactose-free milk (100 mL of milk - $3.3 \mathrm{~g}$ of protein) and received a total of $2.178 \mathrm{~g}$ of protein. Generalised rashes on the body and itching appeared in the process of the trial. The child was given a first-generation antihistamine and a glucocorticosteroid intravenously.

Thus, allergy to cow's milk protein was confirmed in the child. It was recommended that the child should drink $20 \mathrm{~mL}$ of milk every day ( $0.66 \mathrm{~g}$ of protein) to form tolerance to the product. In the absence of exacerbation symptoms, a gradual increase in the product amount was planned under medical supervision.

A multiplex examination (ALEX test) was conducted when the child was two years old.

Total IgE $-8 \mathrm{kU} / \mathrm{L}$.

MILK: cow's milk - Bos d_milk (E) - $1.54 \mathrm{kU}_{\mathrm{A}} / \mathrm{L}$ (Class 2), Bos d $5(\mathrm{M})-0.45 \mathrm{kU}_{\mathrm{A}} / \mathrm{L}$ (Class 1), Bos d 8 (M) $0.30 \mathrm{kU}_{\mathrm{A}} / \mathrm{L}$ (Class 1); goat - Cap h_milk (E) - $1.14 \mathrm{kU}_{\mathrm{A}} / \mathrm{L}$ (Class 2); sheep - Ovi a_milk (E) - $0.69 \mathrm{kU}_{\mathrm{A}} / \mathrm{L}$ (Class 1).

NUTS: hazelnut - Cor_a hazel (E) - $4.30 \mathrm{kU}_{\mathrm{A}} / \mathrm{L}$ (Class 2), hazelnut - Cor a $11(\mathrm{M})-0.34 \mathrm{kU}_{\mathrm{A}} / \mathrm{L}$ (Class 1), hazelnut Cor a $14(\mathrm{M})-6.80 \mathrm{kU}_{\mathrm{A}} / \mathrm{L}$ (Class 3$)$.

WALNUT: Jug r_nut (E) - $3.41 \mathrm{kU}_{\mathrm{A}} / \mathrm{L}$ (Class 2), Jug r 1 (M) - $3.76 \mathrm{kU}_{\mathrm{A}} / \mathrm{L}$ (Class 2), Jug r $2(\mathrm{M})-1.81 \mathrm{kU}_{\mathrm{A}} / \mathrm{L}$ (Class 2). PECAN: Car i (E) - $5.16 \mathrm{kU}_{\mathrm{A}} / \mathrm{L}$ (Class 3$)$.

OTHER: mustard - Sin (E) - $0.51 \mathrm{kU}_{\mathrm{A}} / \mathrm{L}$ (Class 1).

A liberal milk diet could be achieved during 14 months of oral tolerance induction. The child's parents were instructed to stick to the strict elimination of nuts, mustard and their derivatives.

At the age of two years and nine months, the child was given a piece of cake containing nuts, in a restaurant. At that time, the mother was walking outside with another child, and the father was talking to friends. After approximately 
three minutes, the child rapidly became restless, was constantly crying, and his speech ability was impaired. The child's mother was informed about the episode, identified the symptoms and prepared the first aid kit. In five minutes, a generalised rash appeared on the body, in seven minutes - acute pain in the throat and abdomen, in 10 minutes - bronchial obstruction. The mother injected one dose of epinephrine, and did one inhalation of $100 \mu \mathrm{g}$ salbutamol. Gastrointestinal and respiratory symptoms resolved completely in 10 minutes, and rash subsided within 40 minutes, though skin paleness was observed for three hours, and the child complained of headache (associated with epinephrine introduction). No measurement of blood pressure was performed. The boy did not lose consciousness.

The child's parents violated the main rule, that is complete elimination of nuts from the child's diet and monitoring to prevent their accidental penetration into the child's body. Luckily, the boy's mother had been trained in the hospital in first-aid algorithms before the arrival of ambulance, and had been provided with emergency means.

The boy experienced anaphylaxis, with the symptoms developing SYSTEMICALLY (cutaneous, gastrointestinal, respiratory, neurological symptoms) and RAPIDLY (first complaints in three minutes from the moment of product consumption).

\section{Analysis of anaphylaxis cause in the patient}

Storage proteins were detected in the child - Cor a 14, Jug $r$, an allergy to which is often observed throughout lifetime. This group can cause serious systemic reactions, and anaphylaxis. Sensitisation usually occurs in early childhood, even without consumption with food.

Molecule Cor a 14 (Corylus avellana, common hazel) belongs to the family Betulaceae (birch), biological function 2S-albumin, molecular mass - 13-14 kDa.

Description of the allergen. It belongs to the group of storage proteins which are found in hazelnuts in large amounts. It is also present in cotton, sunflower, mustard, sesame and other nuts - Brazilian, walnut, peanut, cashew. It is not associated with plant pollen ${ }^{(9)}$.

Molecule Jug $\mathrm{r} 1$ (Juglans regia, walnut) belongs to Juglandaceae (nuts), biological function - 2S-albumin, molecular weight - 14-16 kDa.

Clinical features: associated with severe reactions.

Consequently, the parents were given the following recommendations based on an analysis of anamnesis data and laboratory findings:

1. Complete elimination of nuts and sesame from the diet and the house where the child lives. It is necessary to be cautious in food and drink venues, as traces of prohibited products may be present in various foods (after baking, preparing sauces, salads or even setting the table).

2. Availability of epinephrine autoinjector. The parents were repeatedly trained in the identification of anaphylaxis symptoms, and rules and methods of administering emergency medicines.

\section{CLINICAL CASE NO. 3}

A girl, 30 months old.

Third-born baby, second delivery. The course of pregnancy and neonatal period were without any abnormalities.

Family anamnesis burdened - the father suffered from pollinosis.

Significant skin dryness was observed during the first year of life, and emollients were used occasionally.

Obstructive bronchitis was observed at the age of one year and nine months; the child was treated on an outpatient basis under family doctor's control.

The family consulted an allergist, but never used hypoallergenic diet.

At the age of two years and three months, the child and parents were in a cottage house. There was dried fish on the table - carp and cod.

The girl was playing with the fish, holding it in her hands. The parents noticed papular fused rashes on her body, respiratory arrest, and whistling at distance, as well as signs of anxiety. The interval until the development of symptoms could not be determined precisely, but it was approximately 20-40 minutes from the moment of contact with an allergen. The parents drove with the girl to a medical establishment urgently and injected dexamethasone and chloropyramine hydrochloride intramuscularly. Signs of acute allergic reaction were observed for the first time.

The girl experienced anaphylaxis, with symptoms developing SYSTEMICALLY (cutaneous and respiratory symptoms) and RAPIDLY (20-40 minutes).

The child was consulted by an allergist, and following a complex examination the ALEX test was conducted.

Total IgE $-2,928 \mathrm{kU} / \mathrm{L}$.

FISH.

Atlantic cod - Gad m (E) - $45.66 \mathrm{kU}_{\mathrm{A}} / \mathrm{L}$ (Class 4), Gad m 1 (M) $-46.67 \mathrm{kU}_{\mathrm{A}} / \mathrm{L}$ (Class 4), Gad m $2+3(\mathrm{M})-3.36 \mathrm{kU}_{\mathrm{A}} / \mathrm{L}$ (Class 2).

Carp - Cyp c $1(\mathrm{M})-42.61 \mathrm{kU} \mathrm{A}_{\mathrm{A}} / \mathrm{L}$ (Class 4).

Atlantic herring - Clu h (E) $-5.79 \mathrm{kU}_{\mathrm{A}} / \mathrm{L}$ (Class 3), Atlantic herring - Clu h $1(\mathrm{M})-49.05 \mathrm{kU}_{\mathrm{A}} / \mathrm{L}$ (Class 4$)$.

Salmon - Sal s (E) - $2.42 \mathrm{kU}_{\mathrm{A}} / \mathrm{L}$ (Class 2), Sal s 1 (M) $45.58 \mathrm{kU}_{\mathrm{A}} / \mathrm{L}$ (Class 4).

Atlantic mackerel - Sco s (E) - $0.53 \mathrm{kU}_{\mathrm{A}} / \mathrm{L}$ (Class 1$)$, Sco s 1 (M) $-48.82 \mathrm{kU}_{\mathrm{A}} / \mathrm{L}$ (Class 4$)$.

Tuna - Thu a (E) - $\leq 0.10 \mathrm{kU}_{\mathrm{A}} / \mathrm{L}$ (Class 0), Thu a $1(\mathrm{M})$ $43.12 \mathrm{kU}_{\mathrm{A}} / \mathrm{L}$ (Class 4$)$.

Swordfish (Xip g 1) - $43.83 \mathrm{kU}_{\mathrm{A}} / \mathrm{L}$ (Class 4 ).

Test results were very unexpected by the parents. They could not believe that the child had developed a severe reaction to fish, since no family members liked fish, and it was almost never available at home. However, there is a scientific explanation for cases such as this one, which is given in the analysis of anaphylaxis causes. 


\section{Analysis of anaphylaxis causes in the patient}

Parvalbumins - Cyp c 1 - carp, Gad m 1 - cod, Clu h 1 - Atlantic herring, Sal s 1 - salmon, Sco s 1 - Atlantic mackerel, Xip g 1 swordfish - were detected in the girl. This group can cause severe systemic reactions, anaphylaxis. Sensitisation can occur in early children's age even without consumption with food.

Molecule Gad c 1 (Gadus morhua, Atlantic cod) belongs to the family Gadidae (codfish), biological function - parvalbumin, molecular weight $12.4 \mathrm{kDa}$.

The allergen belongs to the family of parvalbumins - small calcium-binding buffer proteins which are found in the muscles of vertebrates and participate in muscle relaxation. They are not only the major allergen of cod, but also a marker of allergy to fish. Its allergic activity depends on amino acid motifs, but not protein configuration ${ }^{(14)}$. Sensitisation appears irrespective of thermal processing and the activity of gastrointestinal enzymes. Allergic reactions can occur while consuming fish, inhaling steam during cooking or skin contact. There is significant cross-reactivity between different kinds of fish ${ }^{(6)}$.

Summarising the anamnesis data and available laboratory findings, the child's parents were given the following recommendations:

1. Complete elimination of fish and seafood from the diet and the house where the child lives. It is necessary to be cautious in food and drink venues, as traces of fish protein may be present in various foods (after cooking, frying, and even setting the table). Sushi bars should be avoided.

2. Availability of epinephrine autoinjector. The parents were trained about differentiation of anaphylaxis symptoms, rules and method of introduction of emergency medicines.

3. Dolphinariums and zoos should be avoided, since fish is used for feeding animals. The child should not be taken fishing or to visit fish farms.

4. Regular monitoring by the general practitioner. Planned visit to an allergist in six months.

\section{DISCUSSION}

Nowadays, a broad range of possibilities to diagnose different types of allergy are available. Skin tests represent the first diagnostic method to identify IgE-mediated allergic diseases in patients with a suggestive clinical history of allergic diseases, but they are not recommended in children with severe cases in anamnesis.

Molecular-based allergy diagnosis for the in vitro assessment of a patient immunoglobulin E sensitisation profile at the molecular level is very important for patients with anaphylactic reactions.

It is possible to prognosticate the risk of food anaphylaxis by determining the protein group. The following proteins are significant here:

- storage proteins;

- lipid transfer proteins;

- tropomyosin proteins;

- parvalbumins $^{(2,12)}$.
Storage proteins are stable at thermal processing, associated with severe and systemic reactions: allergens of nuts and seeds. Ara h 1, Ara h 2, Ara h 3 - peanut; Cor a 9, Cor a 14 - hazelnut; Jug r 1, Jug r 2 - walnut; Gly m 5, Gly m 6 - soy; Tri a 19 - wheat. Storage proteins are divided into albumins (2S-albumins) and globulins (7S-globulins and 11S-globulins).

Storage proteins are usually presented by $2 \mathrm{~S}$-albumins, which belong to the superfamily of prolamins that also includes nonspecific lipid transfer proteins, inhibitors of alpha-amylase/ trypsin, prolamin storage proteins of cereal seeds. They are major food allergens contained in the seeds of many plants (monocotyledons and dicotyledons), and serve as an important nutritional medium during germination and growth ${ }^{(5,7)}$. 2S-albumins differ by large amount of sulphur-containing amino acids. They cause sensitisation directly via the gastrointestinal tract; however, high stability of their internal protein structure enables to suggest that these proteins can invade the barrier of intestinal mucosa, causing sensitization and formation of allergic reaction. All 2S-albumins have similar physical and chemical properties, high resistance to heat denaturation (frying, baking, boiling), hydrolysis by gastric proteases (pepsin, trypsin). Therefore, they demonstrate high allergenic properties. However, it should be remembered that not all $2 \mathrm{~S}$-albumins are major allergens. The skeleton of cysteine residue of $2 \mathrm{~S}$-albumins is highly conservative; there is low amino acid sequence similarity inside and outside of plant species. In general, the degree of amino acid sequence similarity of $2 S$-albumins ranges from $14 \%$ to $40 \%$. Although 2S-albumins have high structural homology, cross-reactivity is uncommon in this protein family ${ }^{(7,14)}$.

Lipid transfer proteins are stable at thermal processing, and associated with severe and systemic reactions: allergens of fruit, vegetables, nuts, pollen. Pru p 3 - peach; Mal d 3 apple; Cor a 8 - hazelnut; Jug r 3 - walnut; Ara h 9 - peanut; Tri a 14 - wheat; Gly m 1 - soy ${ }^{(4,5)}$.

Tropomyosin proteins are stable at thermal processing, and associated with severe and systemic reactions. There is high connection and risk of cross-reaction in the family: allergens of seafood, ticks, cockroaches, nematodes - Pen a 1 brown shrimps, Pen $\mathrm{m} 1$ - tiger shrimp ${ }^{(8)}$.

Parvalbumins are stable at thermal processing, and associated with severe and systemic reactions. High risk of crossreactions: allergens of fish and amphibian. Gad c 1 - cod, Cyp c $1-\operatorname{carp}^{(6)}$.

The risk of anaphylaxis in response to food products is given in Tab. $3^{(7)}$.

The administration of adrenaline is the first line in anaphylaxis treatment. The effect of adrenaline administration is the increase in the vascular resistance, blood pressure, coronary perfusion, and oedema reduction due to the $\alpha$-adrenergic effect. Simultaneously, $\beta 1$-adrenergic effect increases the heart rate and the heart's ejection fraction, while the $\beta 2$-adrenergic effect leads to bronchodilation and suppresses the release of inflammatory mediators ${ }^{(6,9)}$.

Various countries have registered different variations of epinephrine autoinjectors. Two main variations are used 


\begin{tabular}{|c|c|c|c|}
\hline \multicolumn{4}{|c|}{ Possibility of provoking an allergic reaction } \\
\hline Parvalbumins & Tropomyosin proteins & Lipid transfer proteins & Storage proteins \\
\hline $\begin{array}{l}\text { Fish and seafood: } \\
\text { Carp - Cyp c } 1 \\
\text { Cod - Gad m } 1 \\
\text { Atlantic herring - Clu h } 1 \\
\text { Salmon - Sal s 1 } \\
\text { Atlantic mackerel - Sco s } 1 \\
\text { Swordfish - Xip g } 1\end{array}$ & \begin{tabular}{|l|} 
Fish and seafood: \\
Brown shrimp - Pen a 1 \\
Tiger shrimp - Pen m 1
\end{tabular} & $\begin{array}{l}\text { Nuts: } \\
\text { Hazelnut - Cor a } 8 \\
\text { Walnut - Jug r } 3 \\
\text { Beans: } \\
\text { Soy - Gly m } 1 \\
\text { Peanut - Ara h } 9 \\
\text { Wheat: } \\
\text { Tri a } 14 \\
\text { Vegetables/fruit: } \\
\text { Peach - Pru p } 3 \\
\text { Apple - Mal d } 3\end{array}$ & $\begin{array}{l}\text { Nuts: } \\
\text { Hazelnut - Cor a 9, Cor a } 14 \\
\text { Walnut - Jug r } 1 \\
\text { Pecan - Car i } 1 \\
\text { Brazil nut - Ber e } 1 \\
\text { Pistachio - Pis v } 1 \\
\text { Cashew - Ana } 03 \\
\text { Almond - Pru du 2S albumin } \\
\text { Beans: } \\
\text { Soy - Gly m 5, Gly m } 6 \\
\text { Chickpea - Cic a 2S albumin } \\
\text { Peanut - Ara h 1, Ara h 2, Ara h 3, Ara h } 6 \\
\text { Wheat: } \\
\text { Tri a 19 } \\
\text { Buckwheat: } \\
\text { Fag e 2 } \\
\text { Mustard: } \\
\text { Eastern - Bra j 1 } \\
\text { Black - Bra ni 2S albumin } \\
\text { Yellow - Sin a } 1 \\
\text { Seed: } \\
\text { Sesame - Ses i 1, Ses i } 2 \\
\text { Sunflower - Hel a 2S albumin }\end{array}$ \\
\hline
\end{tabular}

Tab. 3. Risk of anaphylaxis development to food products(7)

most commonly: $0.15 \mathrm{mg}$ for children weighing $15-25 \mathrm{~kg}$, and devices with $0.3 \mathrm{mg}$ of adrenaline for patients weighing more than $25 \mathrm{~kg}$. For patients weighing up to $15 \mathrm{~kg}$, there is currently no separate autoinjector with adrenaline. However, it has been established based on the literature findings that the excess dose of the medication does not create a risk to the child's health from $7.5 \mathrm{~kg}$ of body weight (maximum dose of $20 \mu \mathrm{g} / \mathrm{kg})^{(4,7)}$.

H1-histamine receptor blockers are administered in cases involving mild clinical symptoms of anaphylaxis (e.g. skin reactions) develop. If necessary, oxygen is provided through a mask, and infusion therapy is performed. Short-acting inhaled $\beta$-2 agonists are used in cases of bronchospasm, delivered through a spacer or a nebuliser ${ }^{(6)}$.

It is necessary to keep the packaging of all medicines administered until the end of the patient's treatment. In children who have experienced anaphylaxis, it is essential to identify the reasons for the reaction and provide further individual training on the health risks and medical care ${ }^{(8,13)}$. The patient should also exclude the group of drugs or a single drug that has caused anaphylaxis (in these particular situations, the physician needs to create a list of prohibited drugs in a written form and a list of alternative medicines) and become capable of predicting cross-reactions and eliminate co-factors. The physician together with the patient should decide whether there is a need to constantly carry an automatic syringe pen with adrenaline, and to conduct a practical training. It is necessary to visualise information on anaphylaxis (a medical ID bracelet, a passport of a patient with anaphylaxis risk) and to provide appropriate information to the

\section{CONCLUSIONS}

1. Difficulties with identifying anaphylaxis in young children are associated with possible development of nonspecific, transitory or less marked clinical symptoms, difficulties in collecting the anamnesis, and subjective assessment of complaints.

2. The major allergens responsible for the development of anaphylaxis in young children include storage proteins, lipid transfer proteins, and parvalbumins.

3. The major components - casein, $\beta$-lactoglobulin and a-lactalbumin - are commonly involved in the development of allergy to cow's milk protein.

4. Each case of anaphylaxis requires exact identification of the cause to be able to compile proper recommendations on the diet and household conditions, and to prevent severe life-threatening reactions in the future.

\section{Conflict of interest}

The authors do not report any financial or personal connections with other persons or organisations that might negatively affect the content of this publication and/or claim authorship rights thereto.

\section{Acknowledgements}

We would like to express our gratitude to all persons who assisted the authors in preparing this article: Head of Communal Non-profit Enterprise "City Children's Clinical Hospital of Lviv" - Dmytro Kvit, and Head of the Allergy Department - Valeriy Lugovskoy, for his comprehensive assistance and encouragement. 


\section{References}

1. James JM, Burks W, Eigenmann P: Food Allergy. Elsevier, 2012: 33-60, 113-127.

2. Besh L, Matsyura O: Food anaphylaxis: analysis of protocol standards, literary data and own clinical experience. Asthma and Allergy 2017; (4): 26-31.

3. Simons FE, Sampson HA: Anaphylaxis: unique aspects of clinical diagnosis and management in infants (birth to age 2 years). J Allergy Clin Immunol 2015; 135: 1125-1131.

4. Thomson H, Seith R, Craig S: Downstream consequences of diagnostic error in pediatric anaphylaxis. BMC Pediatr 2018; 18: 40.

5. Shaker MS, Wallace DV, Golden DBK et al.: Anaphylaxis - a 2020 practice parameter update, systematic review, and Grading of Recommendations, Assessment, Development and Evaluation (GRADE) analysis. J Allergy Clin Immunol 2020; 145: 1082-1123.

6. Jones CJ, Llewellyn CD, Frew AJ et al.: Factors associated with good adherence to self-care behaviours amongst adolescents with food allergy. Pediatr Allergy Immunol 2015; 26: 111-118.

7. Muraro A, Werfel T, Hoffmann-Sommergruber K et al.; EAACI Food Allergy and Anaphylaxis Guidelines Group: EAACI food allergy and anaphylaxis guidelines: diagnosis and management of food allergy. Allergy 2014; 69: 1008-1025.

8. Kurzawa R: Anafilaksja - nie jedno ma imię. Alerg Astma Immun 2017; 22: 30-32.

9. Pampura AN, Esakova NV: [Anaphylaxis in children: problems and solutions]. Ros Vestn Perinatol i Pediatr 2020; 65: 5-10.

10. Dhami S, Nurmatov U, Pajno GB et al.: Allergen immunotherapy for IgE-mediated food allergy: protocol for a systematic review. Clin Transl Allergy 2016; 6: 24.

11. Turner PJ, Campbell DE, Motosue MS et al.: Global trends in anaphylaxis epidemiology and clinical implications. J Allergy Clin Immunol Pract 2020; 8: 1169-1176.

12. Turner PJ, Baumert JL, Beyer K et al.: Can we identify patients at risk of life-threatening allergic reactions to food? Allergy 2016; 71: 1241-1255.

13. Wölbing F, Biedermann T: Anaphylaxis: opportunities of stratified medicine for diagnosis and risk assessment. Allergy 2013; 68: 1499-1508.

14. Gaspar-Marques J, Carreiro-Martins P, Papoila AL et al.: Food allergy and anaphylaxis in infants and preschool-age children. Clin Pediatr (Phila) 2014; 53: 652-657. 